\title{
締固め土のせん断時における間げを水圧の挙動についで*
}

\author{
赤井浩 一** 矢部 正宏***
}

\section{On the Behavior of Pore Pressure during Shear of Compacted Soils}

by

\author{
Koichi Akai and Masahiro YaBe \\ (Kyoto University) (Ministry of Construction)
}

\begin{abstract}
Of great importance in the design of earth structures, such as earth dams, river levees and subgrade or base course of roads, is to know the change of density and strength of compacted soils with their moisture contents. The paper concerns this problem on the basis of pore pressure exerted during shear of soils, through a series of triaxial compression test accompanied by the pore pressure measurement.

Respecting the behavior of pore pressure during shear of compacted unsaturated soils, a lot of experimental data have been obtained which are clearly proved to be quite different from those of undisturbed saturated soils.

(Received May 20, 1961)
\end{abstract}

\section{1. 緒言}

土在締固めるときに，含水量に応じて密度および強 度がどのように变化するかを知ることは，アースダム や河川堤防または道路の路床・路盤など, いわゆる土 椿造物の設計においてきわめて重要であり, 従来から しばしば取り扱われてきたことがらである。しかしこ の問題を締固め土の問げき(隙)水圧の面から検討した 試みはいまだ数少なく、ことにわが国では皆無の状態 である.よって，ここでは締固めた不飽和の土をせん (前)断するとさに発生する間げき水王の举動を実験的 に考究し, 土の締固め機構の解明を試みる.

\section{2. 試料の物理的性質}

試料として用いたのは大阪ちゅう(冲)積層に属する 土であって，次の上うな物性を有している。

比重: $2 \cdot 73$, 粒度組成: 砂分 $(0.05 \mathrm{~mm}$ 以上) $43 \%$, シルト分 $(0.05 \sim 0.005 \mathrm{~mm}) 55 \%$ ，粘土分 $(0.005$ $\mathrm{mm}$ 以下) $2 \%$, 均等係数 $U_{C}=3.58, w_{L}=44.9 \%$, $I_{P}=16 \cdot 6 \%$ ，土質分類： $O L-M L$ 群シルト質口ーム.

Fig. 1 には 3.の試験方法によった場合の締固め曲 線が描かれており，これより最適含水比は $21 \cdot 2 \%$, 最大乾燥密度は $1.65 \mathrm{t} / \mathrm{m}^{3}$ として求められる。

\section{3. 試験装置と方法}

䋨固め用モールドは路床土支持力比 $(\mathrm{CBR})$ 試験に 用いられる内径 $15 \mathrm{~cm}$, 高さ $17 \cdot 5 \mathrm{~cm}$ の真ちゅう製円 筒であって,スペーサー・ディスクは取りはずしてお いた．ランマーも CBR 試験用のもので, 端面の直径

\footnotetext{
* 原稿受付 昭和 36 年 5 月 20 日, 当協会第 10 期総会請演会 (創立 ** 正員 京都大学工学部 10 周年記念）飞て諾演（昭36.5）

**** 建設省士木研究所
}

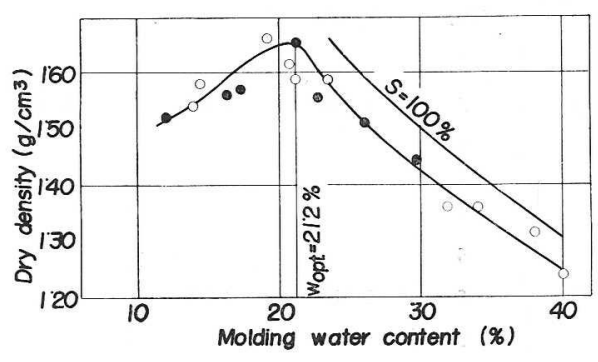

Fig. 1 Compaction curve of the sample tested

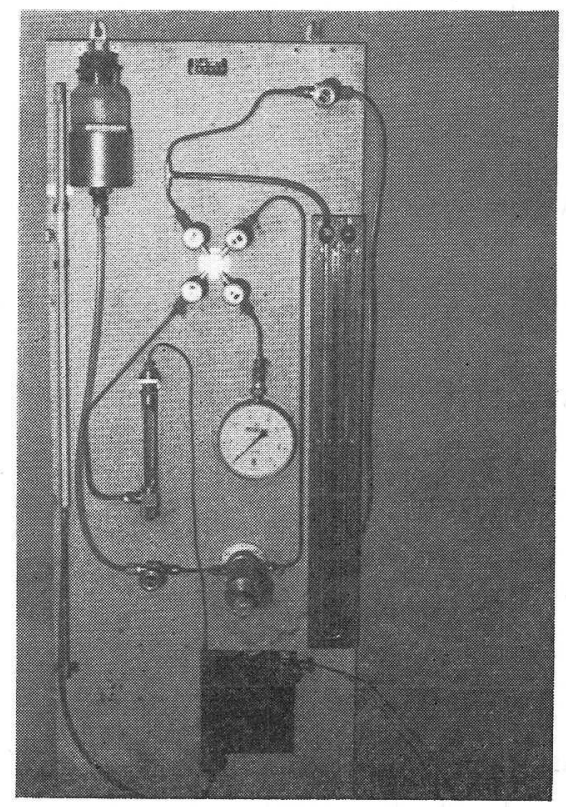

Photo. 1 Pore pressure apparatus 
$5 \mathrm{~cm}$, 重さ $4.5 \mathrm{~kg}$ であり, 落下高を $45 \mathrm{~cm}$ として各 層 25 回，5層に分けて突き固め,これより直径 3.5 $\mathrm{cm}$, 高さ $8 \mathrm{~cm}$ の寸法をもつ一連の供試体を切り出し た (Fig. 1 の黒点の試料について).

締固め土のせん断には，ひずみ制御型の三軸圧縮試 験機を用い，ひずみ速度を每分供試体初期高さ $(8 \mathrm{~cm})$ の $0.5 \%$ に制御して非排水せん断を行ない, この間の 供試体内部の間げき水圧を測定した，間げき水圧測定 装置は Photo. 1 に示す BIC 型のもので，その測定 原理はいわゆる no-flow 方式といわれているものであ る. 三軸压縮室下部のポーラス・ストーンにつながれ たパイプの一端は，この装置中央の毛細管上部に連な り, 毛細管中には水銀を封入している。間げき水圧が 上年すると毛細管中の水銀の頭部に高い圧力がかかる ことになるので，いままで平衡の位置にあった水銀柱
が降下するが，このとき右下にあるハンドルを回して ピストンを押し，毛細管下部に圧力を加えて水銀を押 し上げる，そうして水銀の位置が前と同じ高さ(零点) になったとき，間げき水圧とピストンによって加えら れた圧力が等しいはずであるから，これを水銀マノメ ーターまたはブルドンゲージで読み取ることにより， 供試体内部の間げき水圧を知ることができる，間げき 水圧が減少してきた場合にも同様の操作を行なえばよ い，すなわち，毛細管中の水銀柱先端の位置を絶えず 一定に保ち, 供試体からの排水を許さない状態で平衡 時の圧力を読むのである.

せん断試験において採用した側圧は， $\sigma_{3}=1 \cdot 0,1 \cdot 4$, $1 \cdot 8,2 \cdot 2 \mathrm{~kg} / \mathrm{cm}^{2}$ の 4 種類であって, これを一度に与 えるのではなく， $0.2 \mathrm{~kg} / \mathrm{cm}^{2}$ ずつ段階的に増加させ， 各段階ごとに間げき水圧を測定した。この各段階には

Table 1 Result of ordinary undrained tests

\begin{tabular}{|c|c|c|c|c|c|c|c|c|c|}
\hline $\begin{array}{c}\text { Series } \\
\text { number }\end{array}$ & $\begin{array}{c}\text { Test } \\
\text { number } \\
\text { (No.) }\end{array}$ & $\begin{array}{c}\text { Dry } \\
\text { density } \\
\left(\mathrm{t} / \mathrm{m}^{3}\right) \\
\end{array}$ & $\begin{array}{c}\text { Water } \\
\text { content at } \\
\text { compaction } \\
(\%)\end{array}$ & $\begin{array}{c}\text { Degree of } \\
\text { saturation } \\
(\%)\end{array}$ & $\begin{array}{l}\text { Ambient } \\
\text { pressure } \\
\left(\mathrm{kg} / \mathrm{cm}^{2}\right)\end{array}$ & $\begin{array}{c}\text { Max. } \\
\text { deviator } \\
\text { stress } \\
\left(\mathrm{kg} / \mathrm{cm}^{2}\right)\end{array}$ & \begin{tabular}{|c} 
Pore \\
pressure at \\
compaction \\
$\left(\mathrm{kg} / \mathrm{cm}^{2}\right)$
\end{tabular} & $\begin{array}{c}\text { Pore } \\
\text { pressure } \\
\text { at failure } \\
\left(\mathrm{kg} / \mathrm{cm}^{2}\right)\end{array}$ & $\begin{array}{c}\text { Water } \\
\text { content at } \\
\text { failure } \\
(\%)\end{array}$ \\
\hline \multirow{3}{*}{ I } & 1 & \multirow{3}{*}{$1 \cdot 446$} & \multirow{3}{*}{$29 \cdot 7$} & \multirow{3}{*}{$91 \cdot 2$} & $1 \cdot 0$ & $2 \cdot 05$ & 0.13 & 0.87 & 30.8 \\
\hline & 2 & & & & $1 \cdot 4$ & 1.67 & 0.08 & $1 \cdot 20$ & 29.8 \\
\hline & 3 & & & & $1 \cdot 8$ & $2 \cdot 60$ & 0.15 & $1 \cdot 39$ & 30.4 \\
\hline \multirow{5}{*}{ II } & 4 & \multirow{5}{*}{$1 \cdot 511$} & \multirow{5}{*}{$26 \cdot 1$} & \multirow{5}{*}{$88 \cdot 3$} & $1 \cdot 0$ & $2 \cdot 43$ & 0.13 & 0.40 & $27 \cdot 4$ \\
\hline & 5 & & & & $1 \cdot 4$ & $2 \cdot 06$ & 0.13 & $1 \cdot 11$ & $27 \cdot 8$ \\
\hline & 6 & & & & $1 \cdot 8$ & $1 \cdot 72$ & 0.13 & $1 \cdot 66$ & $28 \cdot 8$ \\
\hline & 7 & & & & $2 \cdot 2$ & $1 \cdot 96$ & 0.20 & $1 \cdot 80$ & $28 \cdot 3$ \\
\hline & 8 & & & & 0.6 & $2 \cdot 15$ & 0.19 & 0.37 & $17 \cdot 5$ \\
\hline \multirow{3}{*}{ III } & 9 & \multirow{3}{*}{$1 \cdot 557$} & \multirow{3}{*}{$22 \cdot 8$} & \multirow{3}{*}{$82 \cdot 7$} & $1 \cdot 0$ & $2 \cdot 75$ & 0.14 & 0.77 & 25.0 \\
\hline & 10 & & & & $1 \cdot 4$ & 3.65 & 0.12 & 0.95 & $25 \cdot 0$ \\
\hline & 11 & & & & $1 \cdot 8$ & $4 \cdot 75$ & 0.17 & 0.86 & $24 \cdot 1$ \\
\hline \multirow{4}{*}{ IV } & 12 & \multirow{4}{*}{$1 \cdot 654$} & \multirow{4}{*}{$21 \cdot 2$} & \multirow{4}{*}{$88 \cdot 9$} & $1 \cdot 0$ & $2 \cdot 85$ & 0.14 & 0.80 & $22 \cdot 8$ \\
\hline & 13 & & & & $1 \cdot 4$ & $4 \cdot 44$ & $0 \cdot 12$ & 1.09 & $21 \cdot 7$ \\
\hline & 14 & & & & $1 \cdot 8$ & $2 \cdot 85$ & 0.15 & $1 \cdot 67$ & $23 \cdot 1$ \\
\hline & 15 & & & & $2 \cdot 2$ & $4 \cdot 11$ & $0 \cdot 16$ & $1 \cdot 51$ & $22 \cdot 4$ \\
\hline \multirow{4}{*}{$\mathrm{V}$} & 16 & \multirow{4}{*}{$1 \cdot 570$} & \multirow{4}{*}{$17 \cdot 3$} & \multirow{4}{*}{$64 \cdot 0$} & $1 \cdot 0$ & $5 \cdot 64$ & 0.14 & 0.51 & $19 \cdot 1$ \\
\hline & 17 & & & & $1 \cdot 4$ & $7 \cdot 71$ & 0.15 & 0.56 & $19 \cdot 7$ \\
\hline & 18 & & & & $1 \cdot 8$ & 5.86 & 0.15 & 0.75 & $19 \cdot 4$ \\
\hline & 19 & & & & $2 \cdot 2$ & $8 \cdot 16$ & 0.18 & 0.78 & $18 \cdot 9$ \\
\hline \multirow{4}{*}{$\mathrm{VI}$} & 20 & \multirow{4}{*}{$1 \cdot 561$} & \multirow{4}{*}{$16 \cdot 4$} & \multirow{4}{*}{$50 \cdot 6$} & $1 \cdot 0$ & $5 \cdot 77$ & 0.14 & 0.38 & $17 \cdot 4$ \\
\hline & 21 & & & & 1.4 & $6 \cdot 12$ & 0.16 & 0.68 & 19.0 \\
\hline & 22 & & & & $1 \cdot 8$ & $8 \cdot 06$ & 0.14 & 0.55 & $18 \cdot 2$ \\
\hline & 23 & & & & $2 \cdot 2$ & $8 \cdot 37$ & 0.13 & 0.47 & $18 \cdot 5$ \\
\hline \multirow{3}{*}{ VII } & 24 & \multirow{3}{*}{$1 \cdot 521$} & \multirow{3}{*}{$12 \cdot 0$} & \multirow{3}{*}{$41 \cdot 3$} & $1 \cdot 0$ & 8.38 & 0.17 & 0.40 & $14 \cdot 3$ \\
\hline & 25 & & & & $1 \cdot 4$ & $6 \cdot 45$ & $0 \cdot 16$ & 0.54 & $17^{\circ} 0$ \\
\hline & 26 & & & & $1 \cdot 8$ & $8 \cdot 42$ & 0.15 & 0.42 & $15 \cdot 2$ \\
\hline
\end{tabular}



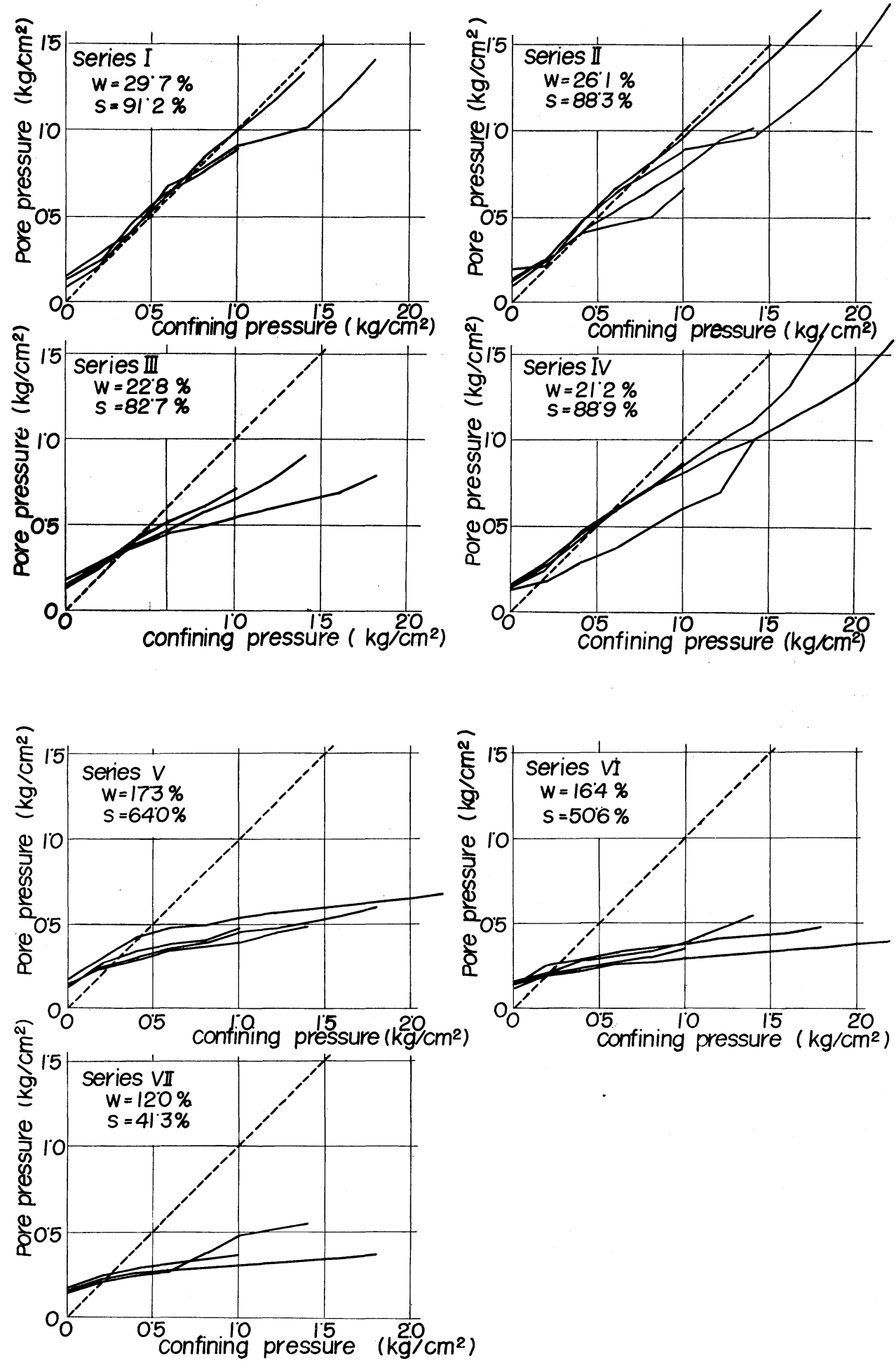

Fig. 2 Correlations between ambient pressure and pore pressure 
ほぼ 2 分間程度の時間間隔をおいたが，これは側圧増 加によって発生する間げき水圧が定常になるのを待つ ためであって，この程度の時間をかけるとほぼその目 的は達成されたようである。

さきに述べた毎分 $0.5 \%$ のひずみ速度は JIS A 1216 (一軸圧縮試験法)に規定されている值の半分であるが， 軸差応力の増加に応じて間げき水圧が充分追随するよ うに考虑したものである。せん断中は 30 秒ごとに， すなわちひずみ 増加 $0.25 \%$ ごとに，軸差応力を測る プルービングリングと間げき水圧計の読みをとって記 録した。

試験終了後は供試体の重量变化を測定し，同時に破 壊時含水比を求めた。 また一部のシリーズの試験では, せん断に先だって供試体に吸水を許す方式を採用した。 これは現実の問題として, 締固められた土が吸水して 含水比を増すことは充分起こりうることであり，その さいに強度がどのように变化するかを知るために行な われたものである。この種の試験では最初側圧を与え ると同時に，間げき水圧測定装置を用いて供試体の下 端から適当な大きさの back pressure を加えて吸水 させ，以後は通常の非排水せん断方式をとった。

\section{4. 試験結果とその考察}

Table 1 に通常の非排水試験（シリーズ $\mathrm{I} \sim \mathrm{VII}$ ) の 結果を総括した.

\section{（I） 側圧の増加による間げき水圧の変化}

三軸圧縮試験機による供試体のせん断に先だち, 先 述のように非排水状態で側圧を $0.2 \mathrm{~kg} / \mathrm{cm}^{2}$ ずつ増加 させて，各段階ごとに間げき水圧を測定した，そのさ いの間げき水圧の変化の様子は Fig. 2 に示すようで あって，飽和度 $S$ が高い場合ほど間げき水圧が大きい ことがわかる。すなわち, 試料が飽和に近づくほど

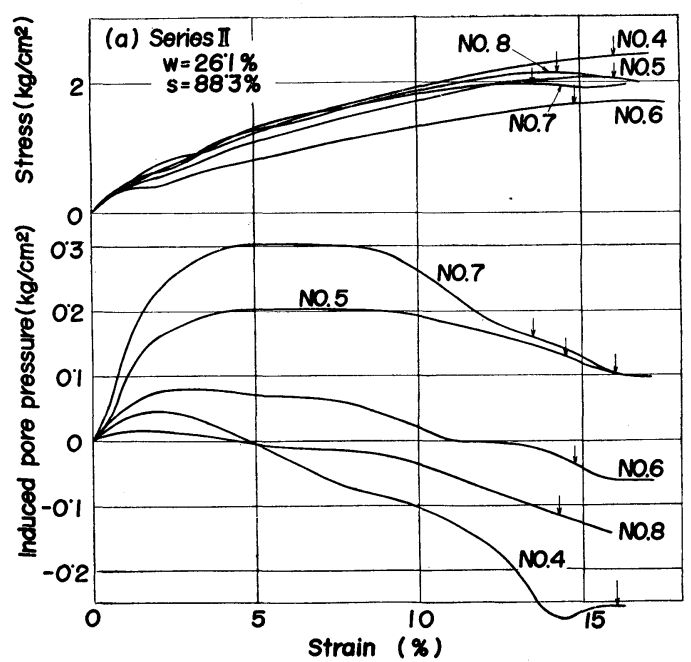

Skemptonの定義した間げき水圧係数 $B=\Delta u / \Delta \sigma_{3}$ は 1 に近づく，図中，両座標軸と $45^{\circ}$ の角度をなす破線 は $B=1$ の場合を示す.

\section{(II) 応力ーひずみ曲線}

三軸圧縮試験における応力ーひずみ曲線の二,三の例 を Fig. 3 (a)〜 (c) の上段に示す。破壞規準としては 軸差応力 $\left(\sigma_{1}-\sigma_{3}\right)$ が最大の場合をとったが，図中の矢 印が破壊点に相当する。

湿潤側の土は乾燥側のそれに比べて応力ーひずみ曲
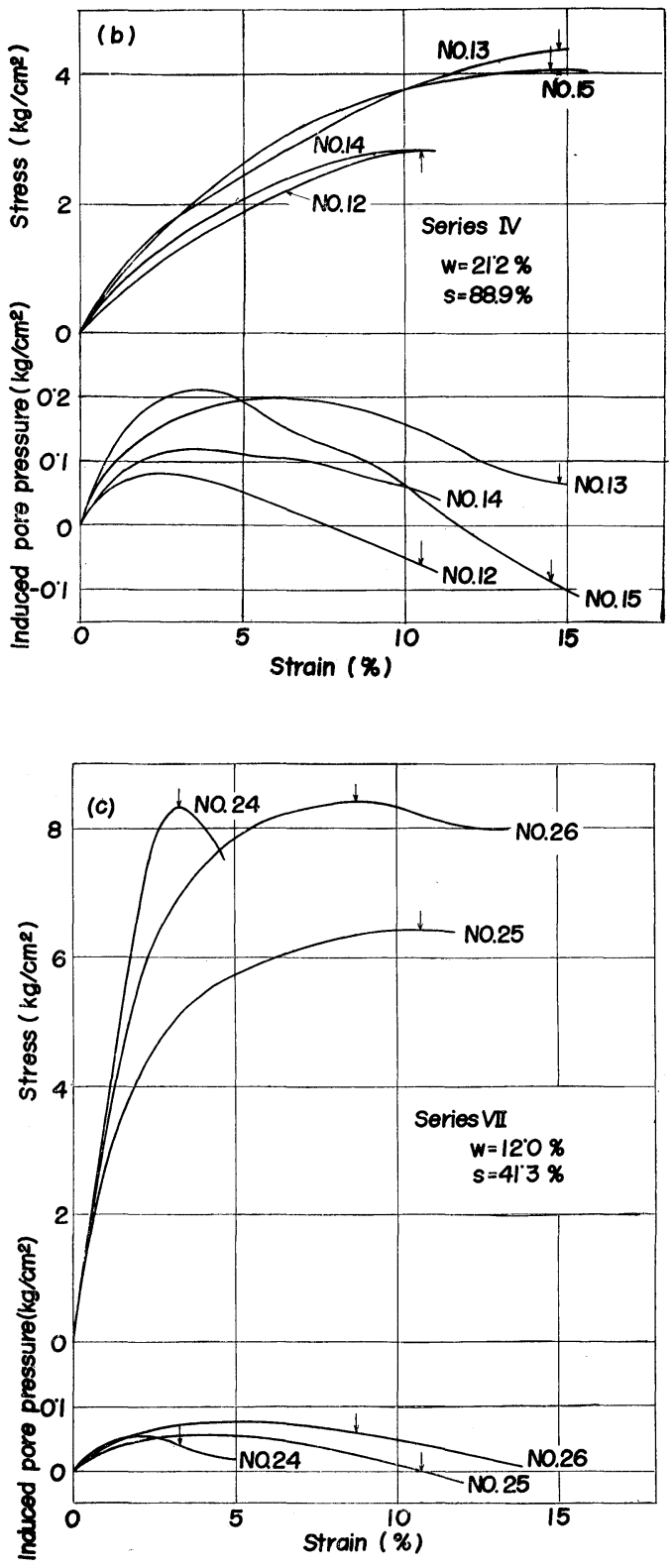

Fig. 3 Stress-strain curves and pore pressurestrain curves in ordinary undrained tests 
線がゆるやかで，破壞点が明確に現われないが，一応 破壊とみなされる点はかなり大きいひずみで生ずる。 これに反して，乾燥側の土の曲線ははるかに急になり， 比較的小さいひずみ量で明確な極值をもつ，一つのシ リーズについていえば，側圧の低い場合に小さいひず みで破壞が生ずる傾向にある。なお乾燥側の試料で応 カーひずみ曲線が極大值を明確に示す場合には，供試 体にせん断面が認められ，その面が最大主応力面とな す角は $60^{\circ} \sim 70^{\circ}$ であった。

\section{（III） せん断時の発生間げき水圧-ひずみ曲線}

軸差応力の増加に伴って起こる間げき水圧の変化の 様子を，上記の応力ーひずみ曲線に対応させて Fig. 3 の各下段に示す．縦軸には，あるひずみのときに測定 された間げき水圧から，試験前に側圧だけによって生 ずる間げき水圧を差し引いた，いわゆる発生間げき水 圧をとった，その一般的な挙動としては，せん断に伴 って間げき水玨が増加し，ほどなく一定值に達してそ の状態をしばらく持続したのち，やがて減少しはじめ る．（II）で述べた規準による破壊時の発生間げき水圧 を矢印で示した（（I)の場合と同様に，含水比したが って飽和度が大きいほど発生間げき水圧が大きいが， その最大值は $\sigma_{3}=2 \cdot 2 \mathrm{~kg} / \mathrm{cm}^{2}$ の側圧に対して高々 0.3 $\mathrm{kg} / \mathrm{cm}^{2}$ にすぎない，同一含水比の土については，側 圧が高くなるほど発生間げき水圧が大きく出る。

せん断が進むにつれて，一時一定であった間げき水 圧が減少しはじめるという現象の共通してみられる点 が飽和土の非排水試験の場合と異なっている。これは 飽和土のせん断と違って不飽和土では，軸差応力を受 けて形状変化をする間に，含水此の変化を伴わないで も容積変化が生ずるというダイレイタンシー特性があ るためである.

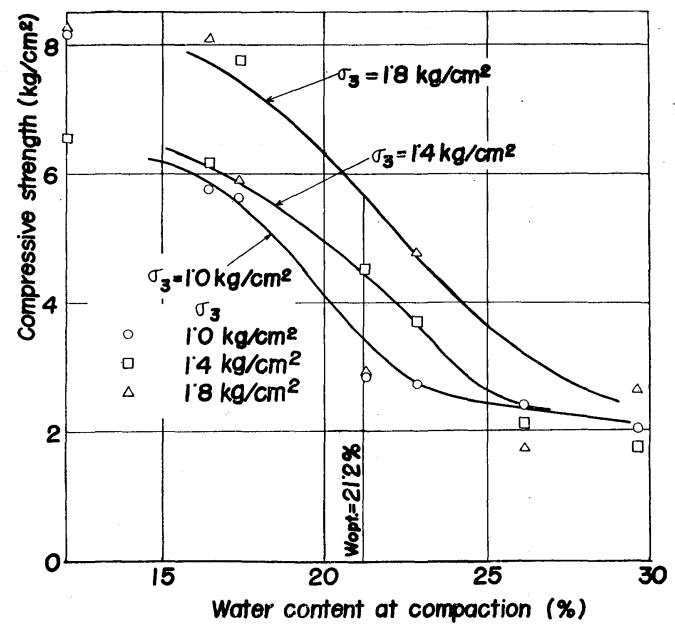

Fig. 4 Maximum deviator stress vs. water content at compaction

\section{(IV) 締固め含水比とせん断強度の関係}

縦軸に破壊時の軸差応力をとり，横軸に締固め時の 含水比をとって, 各側圧に応じて両者の関係を図示し たのが Fig. 4 である。測定值にやや散らばりが認め られるが, $\sigma_{3}=1 \cdot 0,1 \cdot 4,1 \cdot 8 \mathrm{~kg} / \mathrm{cm}^{2}$ の各側圧に対し てほぼ図の曲線のような関係が見られる。この結果か ら締固め含水比がかなり大きいところでは，強度は側 圧にあまり関係しなくなること，および最大強度は最 適含水比よりもなお乾燥側において生ずることが知ら れる。

これらは実際の施工管理において含水量を制御する 場合の一つの指針を与えるが，あまりに乾燥側の土は 吸水する性質があり，それによって含水比が增加して 思わ強度の減少を生ずることが考えられるので，こ の点については (VII)の吸水試験のところで考察を行な うことにする。

\section{（V）破壊時含水比とせん断強度の関係}

縦軸に破壊時の軸差応力, 横軸に破壊時の含水比を とって，両者の関係をプロットしたのが Fig. 5 であ る。締固め含水比と破壊時含水此の相違については Table 1 に示されているが，いずれのシリーズでも後 者のほうが大きく出ている。これは実験が終始非排水 の状態で行なわれたにもかかわらず，供試体の底部が 間げき水压测定用のポーラス・ストーン内の水と接触 するため, 試験中若干の含水量変化が不可避であった ことによるものである.

Fig. 5 の各曲線は Fig. 4 のものをいくらか右側 (含水量の大きい側)へ平行移動させたような形になっ ている。なお, 強度と破壞時含水比との間に, 飽和粘 土では一義的な関係があることを以前に報告しておい たが，締固め土については次のように考えられている. せん断強度の変化は破壊時の間げき比の変化に伴っ

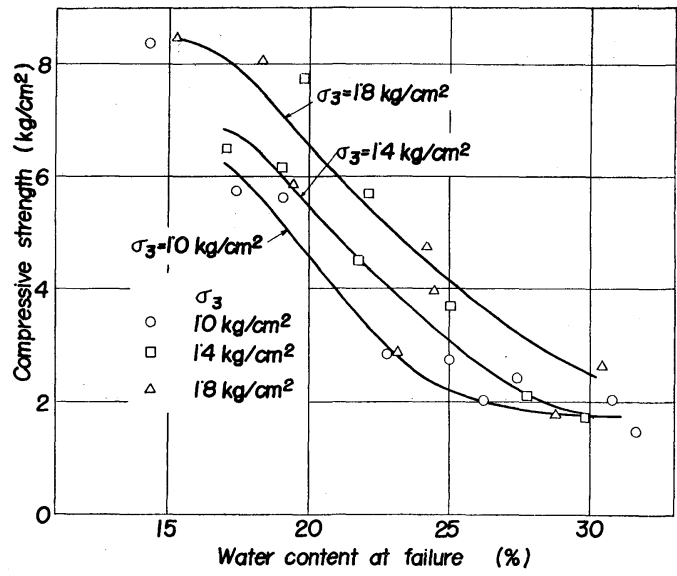

Fig. 5 Maximum deviator stress vs. water content at failure 
て生ずるものであり，その関係は間げき比を変化させ る万法いかんによらない独立のものである。河にに飽 和土においては, 強度の変化は破壊時含水比の変化に 伴ったものでなければならず，含水比と強度の関係は 含水比変化の過程には無関係となる，ところが締固め た土のような不飽和土では, 軸差応力を受けるさいの
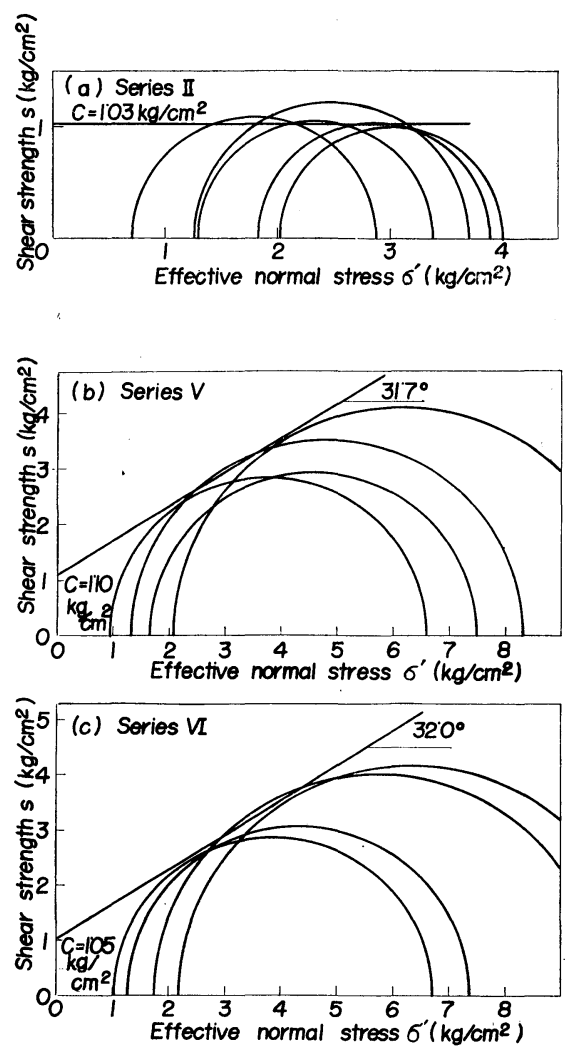

Fig. 6 Mohr's stress circles
間げき比の変化はかなり大きくなることがある上に， これはまた締固め度と側圧に関係するが，含水比の変 化とは無関係に起こる．以上のことから Leonards は 不飽和土の強度変動の型が破壊時の間げき比のみに関 係し，他の因子との間には相関関係がないという結論 を出している.

\section{(VI) Mohr の破壊応力円}

Table 1 のシリーズII, V, VI の各試験結果を有効 応力で整理して描いた Mohr の破壞応力円を Fig. 6 (a), (b), (c) に示す。これらの破壞包絡線を直線とみ なして Coulomb の式

$$
s=c^{\prime}+\sigma^{\prime} \tan \varphi^{\prime}
$$

を適用し, 見掛けの粘着力 $c^{\prime}$ と内部摩擦角 $\varphi^{\prime}$ を求め てみると, 各シリーズについて次の值が得られる。

\begin{tabular}{c|c|c|c}
\hline シリーズ & $\begin{array}{c}\text { 締固め含水此 } \\
(\%)\end{array}$ & $c^{\prime}\left(\mathrm{kg} / \mathrm{cm}^{2}\right)$ & $\varphi^{\prime}$ (度) \\
\hline II & 26.1 & 1.03 & 0 \\
V & 17.3 & 1.10 & $31 \cdot 7$ \\
VI & 16.4 & 1.05 & 32.0 \\
\hline
\end{tabular}

この結果によると, この試料は最適含水比より乾燥 側において内部摩擦角 $\varphi^{\prime} \simeq 32^{\circ}$, 粘着力 $c^{\prime} \simeq 1 \cdot 0 \mathrm{~kg} /$ $\mathrm{cm}^{2}$ の強度定数をもつ.すでに述べたように, 含水比 が大きくなると側圧の相違による強度差がなくなるの で, 含水比の增加とともに内部摩擦角が減少するとい うことが予想される。

\section{(VII) 吸水せん断試験}

締固めた試料に吸水させ，含水比を増加させた後に 行なった非排水せん断試験の結果を総括して Table 2 に示す.また Fig. 7 はこの試験のさいの強度の変動 を調べた結果を図示したものであって，これより次の ことが推論される。

Table 2 Result of undrained tests after soaking

\begin{tabular}{|c|c|c|c|c|c|c|c|c|c|}
\hline $\begin{array}{l}\text { Series } \\
\text { number }\end{array}$ & $\begin{array}{c}\text { Test } \\
\text { number } \\
\text { (No.) }\end{array}$ & $\begin{array}{c}\text { Dry } \\
\text { density } \\
\left(\mathrm{t} / \mathrm{m}^{3}\right)\end{array}$ & $\begin{array}{c}\text { Water } \\
\text { content at } \\
\text { compaction } \\
(\%)\end{array}$ & $\begin{array}{c}\text { Degree of } \\
\text { saturation } \\
(\%)\end{array}$ & $\begin{array}{c}\text { Back } \\
\text { pressure } \\
\left(\mathrm{kg} / \mathrm{cm}^{2}\right)\end{array}$ & $\begin{array}{l}\text { Max. } \\
\text { deviator } \\
\text { stress } \\
\left(\mathrm{kg} / \mathrm{cm}^{2}\right)\end{array}$ & $\begin{array}{c}\text { Pore } \\
\text { pressure at } \\
\text { compaction } \\
\left(\mathrm{kg} / \mathrm{cm}^{2}\right)\end{array}$ & $\begin{array}{c}\text { Pore } \\
\text { pressure } \\
\text { at failure } \\
\left(\mathrm{kg} / \mathrm{cm}^{2}\right)\end{array}$ & $\begin{array}{l}\text { Water } \\
\text { content at } \\
\text { failure } \\
(\%)\end{array}$ \\
\hline \multirow{4}{*}{ VIII } & 27 & \multirow{4}{*}{$1 \cdot 580$} & \multirow{4}{*}{$14 \cdot 4$} & \multirow{4}{*}{$53 \cdot 9$} & 0 & $4 \cdot 84$ & 0.14 & 0.38 & $18 \cdot 9$ \\
\hline & 28 & & & & 0.5 & $2 \cdot 27$ & $0 \cdot 12$ & 0.35 & $24 \cdot 2$ \\
\hline & 29 & & & & 0.5 & $1 \cdot 69$ & 0.14 & 0.41 & $25 \cdot 0$ \\
\hline & 30 & & & & 0.5 & $2 \cdot 68$ & $0 \cdot 18$ & 0.32 & $23 \cdot 2$ \\
\hline \multirow{3}{*}{ IX } & 31 & \multirow{3}{*}{$1 \cdot 587$} & \multirow{3}{*}{$23 \cdot 4$} & \multirow{3}{*}{$88^{\circ} 5$} & 0 & $3 \cdot 70$ & 0.14 & 0.21 & $22 \cdot 8$ \\
\hline & 32 & & & & 0.7 & $3 \cdot 74$ & 0.12 & 0.66 & $22 \cdot 6$ \\
\hline & 33 & & & & 0.7 & $2 \cdot 24$ & 0.17 & 0.85 & $24 \cdot 3$ \\
\hline \multirow{3}{*}{$X$} & 34 & \multirow{3}{*}{$1 \cdot 664$} & \multirow{3}{*}{$19 \cdot 2$} & \multirow{3}{*}{$81 \cdot 8$} & 0 & $3 \cdot 27$ & 0.16 & $0 \cdot 79$ & $22 \cdot 0$ \\
\hline & 35 & & & & 1.0 & $4 \cdot 37$ & 0.19 & 0.33 & $21 \cdot 5$ \\
\hline & 36 & & & & $1 \cdot 0$ & $2 \cdot 64$ & 0.16 & 0.79 & $22 \cdot 7$ \\
\hline
\end{tabular}

$\left(\sigma_{3}=1 \cdot 0 \mathrm{~kg} / \mathrm{cm}^{2}\right)$ 
すなわち低い含水比で締固めた土は back pressure を与えると含水比が大きく増加し, 強度は著しく減少 するが，最適含水比より高い含水比で締固めた土では， 高い back pressure を与えても含水比の増加は少な く, 強度の減少もあまり大きくない（IV)で述べたよ うに，低い含水比で締固めた試料は吸水を許さないと きにはかなり高い強度をもつが，実際の施工において 所要の強度を得るために乾燥側で締固めた場合には, 吸水能力が大きいためにいったん吸水すると非常に強 度を減ずる危険性がある。これに対して湿潤側で締固 めたものは, 締固め時の強度自体があまり大きいもの ではないので, 吸水による強度減少の割合も小さいの である。

しかし Lambe によると，乾燥側の土と乱さない土， 湿潤側の土とねり返した土との間に構造上の相似性が

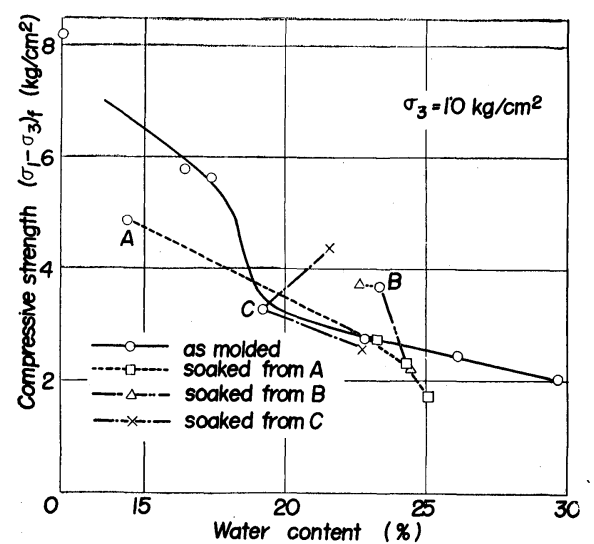

Fig. 7 Strength change of compacted soils due to soaking
ある．このため同一密度で一方は乾燥側，一方は湿潤 側で締固められた試料が容積一定のまま水で飽和する とき, 前者は後者より強度が大きく, しかもその強度 差が土の飽和度の増加につれて減少してくると説明さ れている.

\section{5. 結語}

最適含水比より湿潤側または乾燥側のいずれの含水 量で土を締固めるのが強度の面から適当であるかとい うことは, 盛土をはじめとするあらゆる土構造物の設 計において重要な事項である，本文ではこの問題を土 のせん断時における発生間げき水圧の面から検討する ために，三軸圧縮試験機を用いて一連の実験的考察を 試みた結果を述べた。

ここに記した実験結果からは，一応最適含水比より 湿潤側にある土のほうが吸水後のせん断に対する安定 性がよいという結論が得られたが，一定容積における せん断に対しては今後の研究にまたねばならないもの が少なくない，締固め土のせん断時における間げき水 圧の挙動については詳細な資料が得られ, それが飽和 土とは異なった特性を示すことを明らかにした。

\section{参考 文 献}

1) A.W. Bishop and D.J. Henkel, The Measurement of Soil Properties in the Triaxial Test, 52 (1957) Edward Arnold Ltd.

2) J. Lowe, III and T.C. Johnson, ASCE, Proc. of Research Conference on Shear Strength of Cohesive Soils, 819 (1960)

3) A.W. Skempton, Geotechnique, 4, 143 (1954)

4）赤井, 土木学会論文集, 58, 76 (1958)

5）赤井，材料試験，9，87，772 (1960)

6) 赤井, 柴田, 土木学会誌, 40, 545 (1955)

7) G.A. Leonards, ASCE, Trans., 120, 1420 (1955)

8) T.W. Lambe, ASCE, Proc., 84, SM-2, 1655 (1958) 